\title{
Pharmacological evaluation for anticancer and immune activities of a novel polysaccharide isolated from Boletus speciosus Frost
}

\author{
YILING HOU, XIANG DING, WANRU HOU, BO SONG, TING WANG, FANG WANG, \\ JIAN LI, YICHUN ZENG, JIE ZHONG, TING XU and HONGQING ZHU \\ Key Laboratory of Southwest China Wildlife Resources Conservation, College of Life Sciences, \\ China West Normal University, Nanchong, Sichuan 637009, P.R. China
}

Received May 31, 2013; Accepted February 5, 2014

DOI: $10.3892 / \mathrm{mmr} .2014 .1976$

\begin{abstract}
The fungal polysaccharides have been revealed to exhibit a variety of biological activities, including antitumor, immune-stimulation and antioxidation activities. In the present study, the immune and anticancer activities of a novel polysaccharide, BSF-A, isolated from Boletus speciosus Frost was investigated. The inhibitory rate of S180 tumors in mice treated with $40 \mathrm{mg} / \mathrm{kg}$ BSF-A reached $62.449 \%$, which was the highest rate from the three doses administered; this may be comparable to mannatide. The antitumor activity of BSF-A is commonly considered to be a consequence of the stimulation of the cell-mediated immune response, as it may significantly promote the macrophage cells in the dose range of 100-400 $\mu \mathrm{g} /$ $\mathrm{ml}$ in vitro. The levels of the cytokines, IL- 6 , IL-1 $\beta$ and TNF- $\alpha$, and nitric oxide, induced by BSF-A treatment at varying concentrations in the macrophage cells were similar to the levels in the cells treated with lipopolysaccharide. There was weak expression of the TNF- $\alpha$, IL- 6 , IL- $1 \beta$ and inducible nitric oxide synthase mRNA in the untreated macrophages, but this increased significantly in a dose-dependent manner in the BSF-A-treated cells. BSF-A also had a time- and dose-dependent effect on the growth inhibition of the Hep-2 cells, with the concentration of $400 \mu \mathrm{g} / \mathrm{ml}$ having the highest inhibitory rate. A quantitative PCR array analysis of the gene expression profiles indicated that BSF-A had anticancer activities that affected cell apoptosis in the Hep- 2 cells. The results obtained in the present study indicated that the purified polysaccharide of Boletus speciosus Frost is a potential source of natural anticancer substances.
\end{abstract}

Correspondence to: Dr Xiang Ding, Key Laboratory of Southwest China Wildlife Resources Conservation, College of Life Sciences, China West Normal University, 1 Shida Road, Nanchong, Sichuan 637009, P.R. China

E-mail: starthlh@126.com

Key words: polysaccharide, immune activities, anticancer activities, mechanisms, Boletus speciosus Frost

\section{Introduction}

Mushrooms are a valuable part of obtaining balanced nutrition, and a number of them contain healthy micronutrients, including vitamins and mineral nutrients. Fungal polysaccharides are a type of active organic compound formed by long carbohydrate molecules of repeating units joined together by glycosidic bonds. These polysaccharides are located in the fruiting bodies, mycelium and fermentation broth of large edible and medicinal fungi (1-2). Fungal polysacchardies are often linear, but may also be highly branched, and have been reported to exhibit a variety of biological activities, including antitumor, immune-stimulation and antioxidation activties (2-8). The beneficial effects of a number of fungi, including Agaricus subrufescens (9,10), Ganoderma lucidum (11) and Ophiocordyceps sinensis (12), have been known since ancient times and have been used in traditional Chinese medicine. The lentinan derived from the shiitake mushroom is a source of clinical drugs used in cancer treatments in certain countries, such as Japan $(13,14)$. Polysaccharide-K (Krestin) from Trametes versicolor is also an approved adjuvant for cancer therapy in Europe and Japan (15).

Boletus speciosus Frost is a type of fungi that grows in Xiaojin, Sichuan in China at an elevation of 3,400 m. In our previous study, a novel water-soluble polysaccharide was purified from the fruiting bodies of Boletus speciosus Frost using column chromatography, and its chemical structures were elucidated by various spectroscopic methods (16). The present study aimed to investigate the pharmacological activities and molecular mechanisms of BSF-A, the novel polysaccharide isolated from Boletus speciosus Frost.

\section{Materials and methods}

Isolation of the polysaccharide. The fruiting bodies of Boletus speciosus Frost were collected in Xiaojing, Sichuan, China, and authenticated by Professor Zhirong Yang (College of Life Sciences, Sichuan University, Chengdu, China). The novel water-soluble polysaccharide, BSF-A, was extracted with $95 \%$ ethyl alcohol and purified using a diethylaminoethanol cellulose column and Sephadex G-100 column chromatography (Sigma Aldrich, St. Louis, MO, USA). The Sevag method (17) was used for the 
deproteination of crude BSF polysaccharide, and the eluate from the column chromatography was monitored by the phenol-sulfuric acid method (18). The yield rate of the purified Boletus speciosus Frost polysaccharide, named BSF-A, was $0.215 \%(0.430 \mathrm{~g})$, and the structural features of BSF-A were studied using total hydrolysis, methylation analysis, gas chromatography-mass spectrometry, scanning electron microscopy, infrared spectroscopy, nuclear magnetic resonance spectroscopy and dynamical analysis of the atomic force microscopy. The results indicated that BSF-A had a backbone of $(1 \rightarrow 4)$ - $\alpha$-L-mannopyranose residues that branched at O-6, based on the experimental results. The branches were mainly composed of one residue which was $\rightarrow 1$ )- $\alpha$-D-galactopyranose (Fig. 1).

Microparticle preparation. Microparticles containing purified BSF-A were prepared by the interracial polymerization method under orthogonal design experimental conditions. Briefly, BSF-A was emulsified with $5 \%$ acacia solution (Scharr and Company, Chicago, IL, USA). Following this step, interracial polymerization occurred by adding toluene-2,4-diisocyanate (TDI) and ethylene alcohol (EA; Sigma Aldrich) into the solution in a thermostat-controlled water bath. Finally, the particles were stored at $0^{\circ} \mathrm{C}(19)$. The encapsulation efficiency was determined by a previously described method $(20,21)$. The microcapsules were washed three times with double distilled water, ground by mixing with diatomite and then extracted by the Soxhlet extraction method to obtain the encapsulated BSF-A. The percentage of encapsulation efficiency was calculated using the following equation: Encapsulation efficiency $(\%)=\left(E / E_{0}\right) \times 100$, where $\mathrm{E}$ is the amount of encapsulated BSF-A and $\mathrm{E}_{0}$ is the initial amount of BSF-A.

Animal preparation. In total, 30 male Kunming mice, weighing $25.0 \pm 1.0 \mathrm{~g}$, were purchased from the Institute of Biochemistry and Molecular Immunology of North Sichuan Medical College (NSMC; Nanchong, Sichuan, China). S180 tumor cells were maintained in the peritoneal cavities of the mice. A total of six male Kunming mice were housed per plastic cage, with wood chip bedding and a 12-h light/12-h dark cycle at room temperature $\left(25 \pm 2^{\circ} \mathrm{C}\right)$. The mice were allowed free access to standard laboratory diet, which was purchased from NSMC. The study was approved by the Ethics Committee of China West Normal University (Nanchong, Sichuan, China).

Assay for detecting antitumor activity in vivo. S180 tumor cells $\left(3 \times 10^{6}\right)$ were implanted subcutaneously into the right hind groins of the 30 mice and they were randomly divided into five groups. At one day post-inoculation, the polysaccharide BSF-A was dissolved in distilled water and administered intra-peritoneally (i.p.) to the mice at doses of 10,20 , and $40 \mathrm{mg} / \mathrm{kg}$. Positive and negative controls were set for comparison. In total, $0.2 \mathrm{ml}$ mannatide $(10 \mathrm{mg} / \mathrm{kg})$ was administered i.p. for the positive control, while $0.2 \mathrm{ml}$ physiological saline served as the negative control. The body weights were measured, and the tumors, spleens and livers were excised from the mice at sacrifice after 2 weeks. The tumor inhibitory ratio was calculated by following the
A

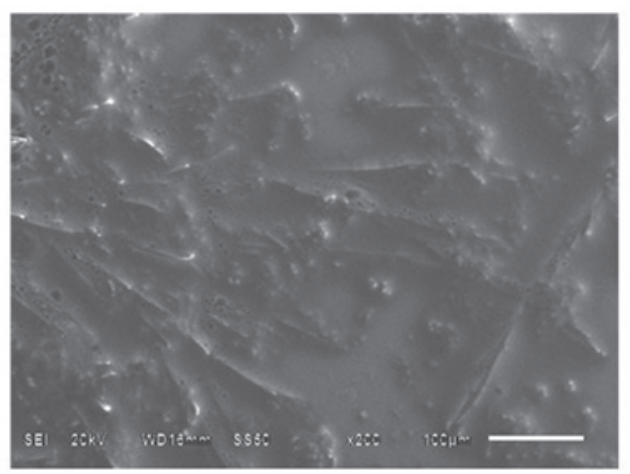

B

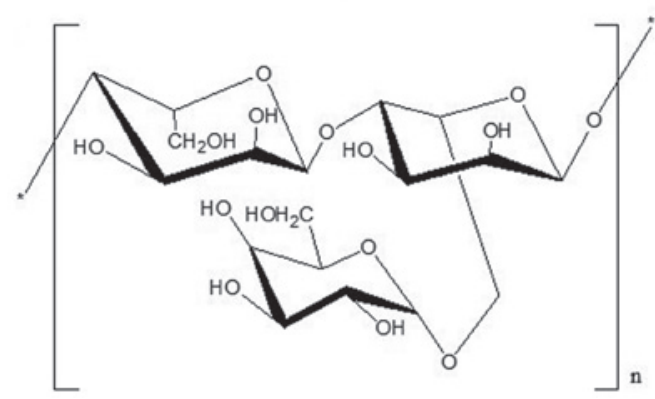

Figure 1. (A) Crystal structure of polysaccharide BSF-A under scanning electron microscope. (B) Predicted chemical structure of polysaccharide BSF-A.

formula: Inhibition ratio $(\%)=[(\mathrm{A}-\mathrm{B}) / \mathrm{A}] \mathrm{x} 100$, where A and $\mathrm{B}$ are the average tumor weights of the negative control and treated groups, respectively.

Histopathological and morphological observations. Following treatment of the mice with BSF-A as described, a portion of the tissues were cut into small sections, fixed in Heidenhain's Suea Fulid $\left(4.5 \mathrm{~g} \mathrm{HgCl}_{2} ; 0.5 \mathrm{~g} \mathrm{NaCl} ; 80.0 \mathrm{ml}\right.$ distilled water; $20.0 \mathrm{ml}$ formalin; $4.0 \mathrm{ml}$ acetic acid; and $2.0 \mathrm{ml}$ trichloroaceticacid) and stained with HE. The sections were examined and images under a microscope (Olympus, Tokyo, Japan) were captured.

Preparation of peritoneal macrophage cells. Six to eight-week-old BALB/c albino mice were injected i.p. with $1 \mathrm{ml}$ 3\% thioglycollate (Sigma Aldrich). Four days after injection, the mice were euthanized and peritoneal exudate cells were collected by lavage with $5 \mathrm{ml}$ sterile cold D-Hank's solution. The exudate cells were collected and cultured in 60-mm dishes with RPMI-1640 (Gibco, Carlsbad, CA, USA) containing 10\% heat-inactivated fetal bovine serum(FBS), penicillin (100 IU/ $\mathrm{ml})$ and streptomycin $(100 \mu \mathrm{g} / \mathrm{ml})$ (RPMI-FBS). Following $1 \mathrm{~h}$ of incubation at $37^{\circ} \mathrm{C}$, the cultures were washed twice with RPMI-1640 to remove non-adherent cells, and the adherent cells were collected by gentle scraping. The viability of the macrophages was assessed using trypan blue exclusion.

Pharmacological evaluation for macrophage stimulation. The macrophage cells $\left(1 \times 10^{6}\right.$ cells $\left./ \mathrm{ml}\right)$ were cultured in a 96-well plate (Corning, Inc., Corning, NY, USA) with phenol red-free RPMI-FBS medium containing increasing concentrations of BSF-A from 50 to $400 \mu \mathrm{g} / \mathrm{ml}(20 \mu 1$ per well) as the experimental group and cells cultured with $20 \mu 1$ lipopolysaccharide 
Table I. Result of primer design.

\begin{tabular}{|c|c|c|c|c|}
\hline Gene & Antisense $\left(5^{\prime}-3^{\prime}\right)$ & Sense $\left(5^{\prime}-3^{\prime}\right)$ & $\mathrm{Tm},{ }^{\circ} \mathrm{C}$ & Product size, bp \\
\hline$\beta$-actin & GCTGTCCCTGTATGCCTCT & TTGATGTCACGCACGATTT & 55.4 & 222 \\
\hline IL-6 & GCCTTCTTGGGACTGATGCTGG & CTCTGGCTTTGTCTTTCTTGTT & 51.7 & 385 \\
\hline TNF- $\alpha$ & GCCTATGTCTCAGCCTCT & GGTTGACTTTCTCCTGGTAT & 53.4 & 423 \\
\hline iNOS & GAGCGAGTTGTGGATTGTC & GGGAGGAGCTGATGGAGT & 55.2 & 376 \\
\hline IL-1 $\beta$ & GCCCATCCTCTGTGACTC & CTGCTTGTGAGGTGCTGA & 52.0 & 434 \\
\hline
\end{tabular}

Tm, temperature; iNOS, inducible nitric oxide synthase.

(LPS; $50 \mu \mathrm{g} / \mathrm{ml}$ ) as the positive control group. Eight repeated wells were used for each concentration. Next, $80 \mu \mathrm{l}$ phenol red-free RPMI-FBS medium was added to each well to make a total volume of $200 \mu 1$. The cell samples were incubated in a $5 \% \mathrm{CO}_{2}$-air mixture at $37^{\circ} \mathrm{C}$ for $4 \mathrm{~h}$ and $50 \mu \mathrm{l}$ neutral red solution was added to a final concentration of $0.72 \mathrm{mg} / \mathrm{l}$. The culture was left for $30 \mathrm{~min}$. The neutral red solution was aspirated, washed three times with PBS and then $200 \mu 1$ lysis buffer was added (glacial acetic acid:ethanol, 1:1). The optical density (OD) was evaluated following complete cell lysis.

Nitric oxide concentration determination. The amount of stable nitrite and $100 \mu \mathrm{L}$ culture supernatants were mixed with an equal volume of Griess reagent (1\% sulfanilamide, $0.1 \%$ naphthylethylenediamine dihydrochloride and $2.5 \%$ $\mathrm{H}_{3} \mathrm{PO}_{4}$ ). This mixture was incubated at room temperature for $10 \mathrm{~min}$ and the absorbance at $540 \mathrm{~nm}$ was read using a Thermo multiskan ascent reader (Thermo Fisher Scientific, Waltham, MA, USA). The nitric oxide concentration was determined by extrapolation based on a standard sodium nitrite curve (22).

Cytokine determination. The amount of TNF- $\alpha$, IL- 6 and IL-1 $\beta$ from the culture supernatants was determined using an ELISA kit (R\&D Systems, Shanghai, China) following the manufacturer's instructions.

qPCR detection of related gene expression. The peritoneal macrophages were harvested following stimulation by various concentrations of BSF-A for $4 \mathrm{~h}$. Total cellular RNA was extracted using TRIzol reagent (Invitrogen, Carlsbad,CA,USA) and reverse transcribed into cDNA using oligo $(\mathrm{dT})_{18}$ primers (Invitrogen). Amplification of each target cDNA was performed using the icycler system (Bio-rad, Hercules, CA, USA), and the PCR products were quantified using SYBR Green I. $\beta$-actin was used as an endogenous control to normalize expression levels among samples, and a standard curve of each primer set was generated using LPS-induced macrophage cDNA. The PCR primers selected are shown in Table I. Relative expression abundance was calculated using the formula: Relative expression abundance $=$ moles of detected mRNA $/$ moles of $\beta$-actin mRNA.

Cell culture. Human laryngeal carcinoma Hep-2 and hepatoma HepG2 cell lines were grown in RPMI-1640 medium supplemented with $10 \%$ heat-inactivated fetal bovine serum, $100 \mathrm{IU} / \mathrm{ml}$ penicillin, $100 \mu \mathrm{g} / \mathrm{ml}$ streptomycin and
$10 \mathrm{mM}$ 2-[4-(2-hydroxyethyl)-1-piperazinyl] ethanesulfonic acid (HEPES) at $\mathrm{pH} 7.4$. The cells were kept at $37^{\circ} \mathrm{C}$ in a humidified $5 \% \mathrm{CO}_{2}$ incubator.

Testing the effect of BSF-A on human laryngeal carcinoma Hep-2 and hepatoma HepG2 cell activity by the MTT method. The two cell lines were seeded into 96-well microculture plates at appropriate densities to maintain the cells in an exponential phase of growth throughout the duration of the experiment. The human laryngeal carcinoma Hep-2 and hepatoma HepG2 cells were exposed to BSF-A at 0, 25, 50, 100, 200 and $400 \mu \mathrm{g} / \mathrm{ml}$ for $24 \mathrm{~h}$, and each concentration was evaluated in six separate wells. At the end of the exposure, $20 \mu \mathrm{l}$ MTT was added to each well and the plates were incubated for $2-4 \mathrm{~h}$ at $37^{\circ} \mathrm{C}$. Next, $150 \mu$ ldimethyl sulfoxide was added to each well and the agitated for $5 \mathrm{~min}$. The OD was read using a plate reader (Biorad) at a wavelength of $490 \mathrm{~nm}$. Media-alone wells and control wells, in which BSF-A was absent, were included in all the experiments. The degree of inhibition of cell proliferation was calculated using the following formula: Growth inhibition $(\%)=(\mathrm{OD}$ control $-\mathrm{OD}$ treated $) / \mathrm{OD}$ control $\mathrm{x} 100$.

Morphological observation of cells. The 96-well microculture plates into which the human laryngeal carcinoma Hep-2 and hepatoma HepG2 cells had been seeded were observed by inverted microscopy (Olympus). Images of the changes in the conformation of the cells were captured and recorded.

PCR design. This study used the apoptosis PCR array from CT Bioscience (Changzhou, Jiangsu, China) to compare the expression profiles of a selected group of genes at various disease stages. The PCR array employs SYBR Green I-based qPCR to quantify gene expression levels. Gene specific primers were pre-deposited into the wells of a 96-well PCR plate in the array. Each PCR array quantified the mRNA levels of 88 selected target genes and six reference genes. The reference genes were used to normalize the target gene expression levels. In addition, each PCR array had one PCR positive control and one genomic DNA control for quality control purposes. The PCR positive control contained artificial templates and PCR primer pairs that specifically amplified this template. This was designed to monitor the PCR step. The genomic DNA control measured the residual genomic DNA potentially present in the RNA samples.

Primer design and selection. Primers were designed to cover all transcripts of a gene. Primer design also took the following 
Table II. Antitumor activities of BSF-A on S180 tumor (mean $\pm \mathrm{SD}, \mathrm{n}=8$ ).

\begin{tabular}{lccccc}
\hline Group & Spleen index, $\mathrm{mg} / \mathrm{g}$ & Liver index, $\mathrm{mg} / \mathrm{g}$ & Thymus index, $\mathrm{mg} / \mathrm{g}$ & $\begin{array}{c}\text { Average tumor } \\
\text { weight, } \mathrm{g}\end{array}$ & $\begin{array}{c}\text { Inhibitory rate } \\
\text { of tumor, } \%\end{array}$ \\
\hline N & $5.624 \pm 1.912$ & $59.509 \pm 8.820$ & $1.430 \pm 0.740$ & $3.707 \pm 0.361$ & - \\
B1 & $7.817 \pm 2.405$ & $54.519 \pm 4.397$ & $4.861 \pm 0.339$ & $2.051 \pm 0.727$ & $44.672^{\mathrm{a}}$ \\
B2 & $7.801 \pm 3.238$ & $63.311 \pm 7.272$ & $7.901 \pm 2.803$ & $1.738 \pm 0.501$ & $53.116^{\mathrm{a}}$ \\
B3 & $5.001 \pm 0.891$ & $59.053 \pm 4.407$ & $0.801 \pm 0.194$ & $1.392 \pm 0.211$ & $62.449^{\mathrm{a}}$ \\
M & $7.022 \pm 2.917$ & $56.212 \pm 4.872$ & $2.726 \pm 1.137$ & $1.612 \pm 0.669$ & $56.515^{\mathrm{a}}$ \\
\hline
\end{tabular}

Significant differences from the negative and positive control groups were evaluated using Student's t-test; ${ }^{\text {a }}<0.01$. N, negative control group; B1, B2, B3, BSF-A groups of 10, 20 and $40 \mathrm{mg} / \mathrm{kg}$, respectively; M, positive control group treated with mannatide.

into consideration: All primers had a similar melting temperature $(\mathrm{Tm})$; the primers did not contain known single nucleotide polymorphisms; the primers were not located in genomic repetitive regions; and in the majority of cases, the primers differed from non-target sequences by three or more bases, as revealed by a Blast search. The primers were experimentally selected if they met the following criteria: The amplification presented a typical amplication curve, and a post-PCR melting curve analysis demonstrated a single peak.

Sample analysis. Hep-2 cell group total RNA $(1 \mu \mathrm{g})$ was used for reverse transcription using a RT kit (Cat no. CTB101, CT Bioscience) in a $20-\mu l$ volume. Following reverse transcription, RT products were diluted using $\mathrm{ddH}_{2} \mathrm{O}$ to $1,000 \mu \mathrm{l}$. The diluted RT products were mixed with $1 \mathrm{ml} 2 \mathrm{X}$ SYBR Green MasterMix (Cat no. CTB103, CT Bioscience), and $20 \mu \mathrm{l}$ of the mixture was aliquoted into each well of the 96-well PCR array. The sealed PCR plate was loaded onto an ABI 7500 (Applied Biosystems, Grand Island, NY, USA) instrument. The cycling conditions were as follows: $95^{\circ} \mathrm{C}$ for $5 \mathrm{~min}$ to activate hotstart Taq, then $95^{\circ} \mathrm{C}$ for $15 \mathrm{sec}, 60^{\circ} \mathrm{C}$ for $1 \mathrm{~min}$ and $72{ }^{\circ} \mathrm{C}$ for $45 \mathrm{sec}$ for 40 cycles. The melting curve analysis was performed using $95^{\circ} \mathrm{C}$ for $5 \mathrm{sec}$ and $65^{\circ} \mathrm{C}$ for $1 \mathrm{~min}$.

Data analysis. This study used the classical ${ }^{\Delta \Delta} \mathrm{Ct}$ method to perform relative quantification. ${ }^{\Delta A} \mathrm{Ct}=(\mathrm{Ct}$ of target sample - $\mathrm{Ct}$ of reference sample) - $(\mathrm{Ct}$ of target control - $\mathrm{Ct}$ of reference control). ${ }^{\Delta \Delta} \mathrm{Ct}$ was used to calculate the expression fold change. The formula used was as follows: Expression fold changes $=$ target gene expression level of experiment sample / target gene expression level of control sample $=2^{\wedge}(-\Delta \Lambda C t)$. The data are expressed as the mean $\pm \mathrm{SD}$. The significance of the differences were evaluated with a one-way ANOVA, followed by the Student's t-test to statistically identify differences between the control and treated groups. $\mathrm{P}<0.05$ and $\mathrm{P}<0.01$ were used to indicate statistically significant differences.

\section{Results and discussion}

Antitumor activity of BSF-A in vivo. Microencapsulation was undertaken since the water solubility of the polysaccharide was poor. Attention was focused on preserving the biological activity of BSF-A. Microencapsulation of BSF-A was perfomed

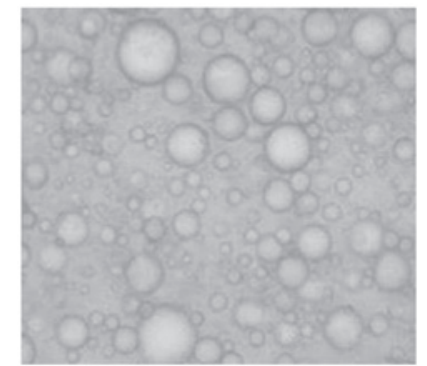

Figure 2. Captured images of microcapsules of BSF-A (magnification, $\mathrm{x} 400$ ).

by interracial polymerization (23) using poly-TDI-EA (Fig. 2). This procedure avoids the shear stress produced by sonication that would normally effect the integrity of the drugs and consequently, their biological activity (24).

The antitumor activity of a polysaccharide is believed to be the result of the stimulation of the cell-mediated immune response (25). In order to detect the antitumor activity of BSF-A in vivo, the mice transplanted with S180 cells were used to evaluate its effects. The results are summarized in Table II. The weight and histological preparations of the vital organs in each male rat in the control group were compared with that in the treated group in order to measure the effect of the drug. BSF-A was able to inhibit the growth of the tumors $(\mathrm{P}<0.01)$ in a dose-dependent manner. The inhibitory rate in the mice treated with $40 \mathrm{mg} / \mathrm{kg}$ BSF-A was $62.449 \%$ and was the highest amongst the three doses administered. Furthermore, during the course of the experiments, the appetite, activity and coat luster of each animal in the BSF-A groups were improved compared with the mice treated with mannatide. Compared with the vigorous growth of the normal saline group (Fig. 3), massive necrotic areas were present in the tumor tissue, which was divided into small tumor cell groups within the BSFA-treated group. As the concentration of the BSF-A polysaccharide increased, the tumor cell groups were encapsulated in muscular tissue and the growth of the tumor cells was inhibited. The results also revealed little change in the average liver weight of the test groups, which indicated that BSF-A did not cause serious liver damage. On the 14th day, the average tumor weight of the negative control mice was $3.707 \mathrm{~g}$, whereas the average tumor weight of the mice in the $40-\mathrm{mg} / \mathrm{kg}$ BSF-A group was $1.392 \mathrm{~g}$. The weight was also 

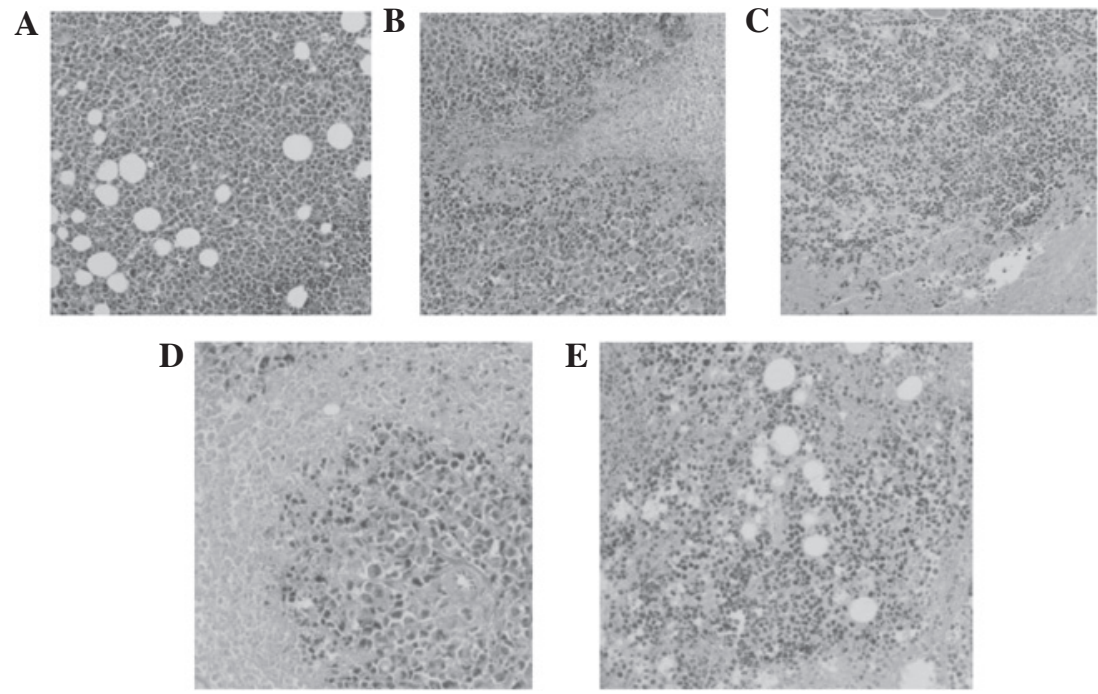

Figure 3. Histopathology of tumors from the S180 cell-bearing mice. (A) Negative control group; (B, C and D) BSF-A groups of 10, 20 and $40 \mathrm{mg} / \mathrm{kg}$, respectively; and (E) positive control group of mannatide (HE staining; magnification, x200).

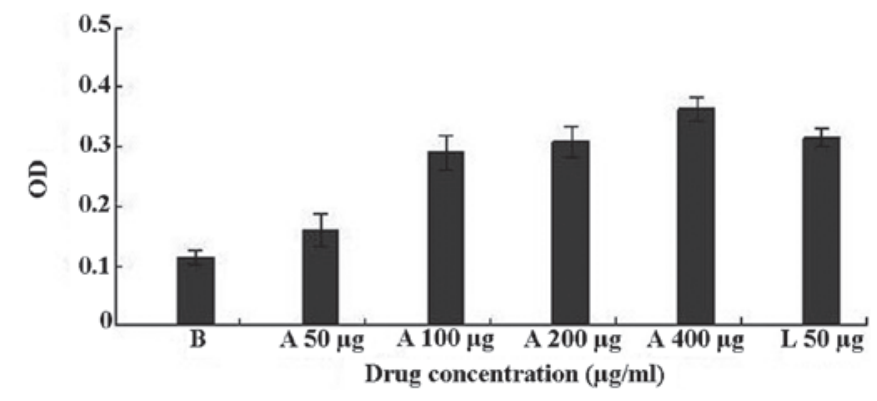

Figure 4. Effect of BSF-A and LPS on mouse macrophage cells. B, blank control group; L, LPS group; A, BSF-A group (mean $\pm \mathrm{SD}, \mathrm{n}=8$ ). LPS, lipopolysaccharide.

significantly reduced to $2.051 \mathrm{~g}$ and $1.738 \mathrm{~g}$ following treatment with doses of $10 \mathrm{mg} / \mathrm{kg}$ and $20 \mathrm{mg} / \mathrm{kg}$, respectively. It is noteworthy that the average weights of the spleens and thymus in the test groups were significantly increased following administration of $20 \mathrm{mg} / \mathrm{kg}$ BSF-A compared with the weights in the mannatide or negative control mice. This indicates that BSF-A is able to increase the weights of immune organs in moderate doses (Table II) and that activating the immune responses in the host may be one of the mechanisms for the antitumor activity of BSF-A and a number of other antitumor polysaccharides.

Immune activity of BSF-A in vitro. The antitumor activity of a polysaccharide is believed to be the result of the stimulation of the cell-mediated immune response (25). The present study revealed the immune activity of BSF-A using a macrophage stimulation assay. Polysaccharides are good stimulators of macrophages due to the presence of various receptors on the macrophage membrane. In the present study, BSF-A was able to significantly promote the phagocytosis of the mouse peritoneal macrophages within the dose range of $100-400 \mu \mathrm{g} / \mathrm{ml}$ compared with the control group $(\mathrm{P}<0.01$; Fig. 4) and the best stimulatory capacity of BSF-A was at a dose of $400 \mu \mathrm{g} / \mathrm{ml}$ with an OD value of 0.36 .
The stimulatory capacity of BSF-A on macrophage cells and the concentration of BSF-A were positively correlated.

BSF-A enhances cytokine production in peritoneal macrophage cells. Using the ELISA method, the level of IL-6 and TNF- $\alpha$ secreted by the BSF-A-activated macrophages was compared with the control. The levels of the two cytokines secreted by the BSF-A-stimulated macrophages was much higher than that secreted by the medium-treated macrophages. LPS $(50 \mu \mathrm{g} / \mathrm{ml})$ was used as the positive control. The level of cytokines induced by BSF-A treatment at varying concentrations was similar to the level induced by LPS. It is notable that the production of IL- 6 was stimulated at high levels when the concentration of BSF-A was only $50 \mu \mathrm{g} / \mathrm{ml}$ (Table III).

BSF-A stimulates the expression of $T N F-\alpha, I L-6, I L-1 \beta$ and inducible nitric oxide synthase (iNOS) $m R N A$. The qPCR results showed a significant increase in the levels of TNF- $\alpha$, IL-6, IL-1 $\beta$ and iNOS mRNA in the BSF-A-treated peritoneal macrophages compared with those that were untreated. The positive control, LPS $50 \mu \mathrm{g} / \mathrm{ml}$, also promoted the expression of these genes. The expression of all the genes studied in the untreated macrophage was weak, but increased significantly in a dose-dependent manner in the BSF-A-treated cells (Table IV).

The role of activated macrophages in the defense against tumor cells has been investigated extensively over the last few decades (26-28). Accumulated evidence indicates that activated macrophages are able to recognize and lyse tumor cells, including those that are resistant to cytostatic drugs. Therefore, macrophage activation may play a role in novel immunotherapeutic approaches to the treatment of cancer (28). Macrophages are able to kill tumor cells either by macrophage-mediated tumor cytotoxicity or antibody-dependent cellular cytotoxicity. These processes are likely to result in the same manner of release as the cytotoxic mediators, including TNF- $\alpha, \mathrm{NO}$ and reactive oxygen intermediates, or phagocytosis (29). TNF- $\alpha$ is one of the most significant mediators involved in tumor cell death by the induction of multiple intracellular pathways, 
Table III. Production of NO and cytokines in PM stimulated by BSF-A. (mean \pm SD, n=6).

\begin{tabular}{lcrrrr}
\hline Group & N & A1 & A2 & A3 & L \\
\hline TNF- $\alpha, p g / m l$ & $120.4 \pm 8.8$ & $158.5 \pm 5.4^{\mathrm{a}}$ & $167.4 \pm 4.1^{\mathrm{a}}$ & $174.0 \pm 2.6^{\mathrm{a}}$ & $176.3 \pm 4.7^{\mathrm{a}}$ \\
NO,$\mu \mathrm{m}$ & $2.4 \pm 0.2$ & $8.5 \pm 0.1^{\mathrm{a}}$ & $10.5 \pm 0.3^{\mathrm{b}}$ & $11.4 \pm 0.6^{\mathrm{b}}$ & $9.5 \pm 0.5^{\mathrm{b}}$ \\
IL-6, pg/ml & $201.7 \pm 11.4$ & $832.4 \pm 9.7^{\mathrm{b}}$ & $843.1 \pm 14.7^{\mathrm{b}}$ & $877.3 \pm 11.7^{\mathrm{b}}$ & $884.9 \pm 15.8^{\mathrm{b}}$ \\
IL- $1 \beta, \mathrm{pg} / \mathrm{ml}$ & $104.4 \pm 7.9$ & $151.2 \pm 7.3^{\mathrm{b}}$ & $154.3 \pm 5.9^{\mathrm{b}}$ & $157.4 \pm 4.5^{\mathrm{b}}$ & $163.2 \pm 5.4^{\mathrm{b}}$ \\
\hline
\end{tabular}

Significant differences from negative and positive control groups were evaluated using Student's $t$ test; ${ }^{\text {a }} \mathrm{P}<0.05$ and ${ }^{\mathrm{b}} \mathrm{P}<0.01$. N, negative control group; A1, A2, and A3, BSF-A groups of 50, 200 and $400 \mu \mathrm{g} / \mathrm{ml}$, respectively; L, positive control group of LPS $50 \mu \mathrm{g} / \mathrm{ml}$ group. NO, nitric oxide; PM, peritoneal macrophage cells.

Table IV. Expression of TNF- $\alpha$, iNOS, IL-6 and IL-1 $\beta$ mRNA in PM stimulated by BSF-A (mean \pm SD, $n=6)$.

\begin{tabular}{lccccc}
\hline Group & $\mathrm{N}$ & $\mathrm{A} 1$ & $\mathrm{~A} 2$ & $\mathrm{~A} 3$ & $\mathrm{~L}$ \\
\hline TNF- $\alpha$ & $0.01 \pm 0.00$ & $0.17 \pm 0.01^{\mathrm{a}}$ & $0.28 \pm 0.02^{\mathrm{a}}$ & $0.47 \pm 0.04^{\mathrm{a}}$ & $0.14 \pm 0.02^{\mathrm{a}}$ \\
NO & $0.12 \pm 0.01$ & $0.69 \pm 0.03^{\mathrm{a}}$ & $1.36 \pm 0.21^{\mathrm{a}}$ & $1.54 \pm 0.14^{\mathrm{a}}$ & $1.27 \pm 0.26^{\mathrm{a}}$ \\
IL-1 $\beta$ & $0.01 \pm 0.01$ & $0.13 \pm 0.02^{\mathrm{a}}$ & $0.37 \pm 0.02^{\mathrm{a}}$ & $0.43 \pm 0.01^{\mathrm{a}}$ & $0.11 \pm 0.01^{\mathrm{a}}$ \\
IL-6 & $0.01 \pm 0.00$ & $0.23 \pm 0.01^{\mathrm{a}}$ & $0.59 \pm 0.02^{\mathrm{a}}$ & $1.03 \pm 0.08^{\mathrm{a}}$ & $0.12 \pm 0.01^{\mathrm{a}}$ \\
\hline
\end{tabular}

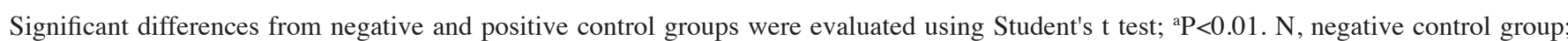
A1, A2 and A3, BSF-A groups of 50, 200 and $400 \mu \mathrm{g} / \mathrm{ml}$, respectively; L, positive control group of LPS $50 \mu \mathrm{g} / \mathrm{ml}$ group. PM, peritoneal macrophage cells; iNOS, inducible nitric oxide synthase.

A

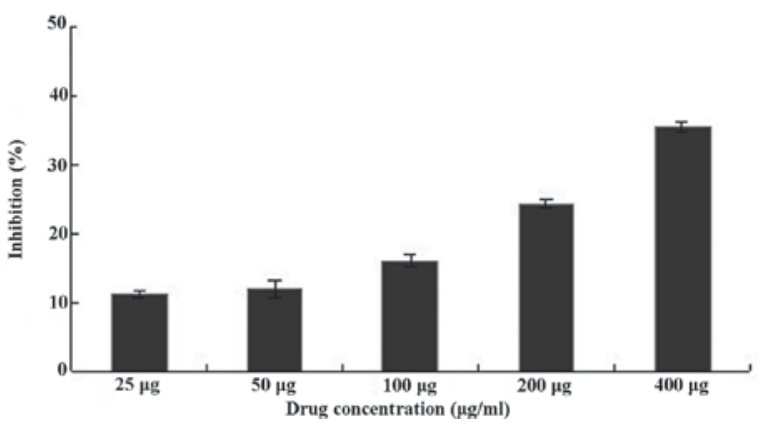

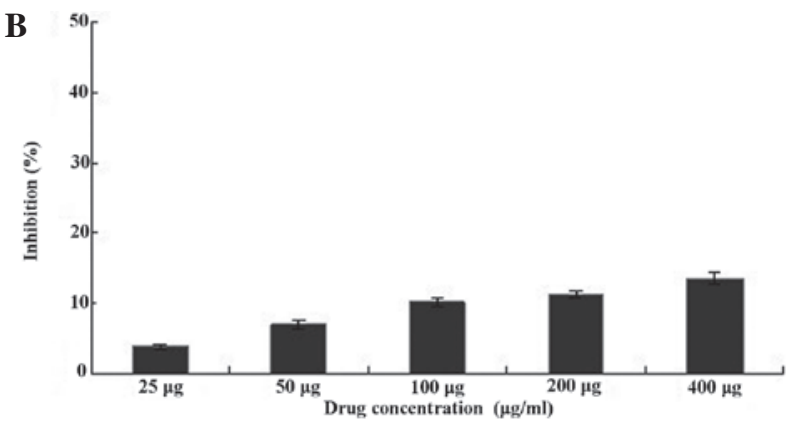

Figure 5. Cell growth inhibition of BSF-A on (A) human laryngeal carcinoma Hep-2 cells (B) and human hepatoma HepG2 cells. Hep-2 cells treated with $25-400 \mu \mathrm{g} / \mathrm{ml}$ BSF-A for 24-h exhibited significant cell growth inhibition compared with the control (P<0.01), as observed by MTT assay, while HepG2 cells exhibited no significant change.

including the generation of reactive oxygen intermediates in the mitochondria preceding plasma membrane permeabilization (30) and the induction of iNOS expression. Ultimately, these processes may lead to cell death. BSF-A increases the secretion of the TNF- $\alpha$ of macrophages and the expression of TNF- $\alpha$ mRNA in vitro. The toxic effects of NO and its derivatives on target cells are due to several mechanisms (31). The results of the present study demonstrated that BSF-A was able to increase the release of $\mathrm{NO}$ and induce the expression of the iNOS gene to several folds higher in vitro. Taken together, these results indicate that it is reasonable to assume that the release of TNF- $\alpha$ and NO, which is activated by BSF-A, may be a significant mechanism of the antitumor effect of BSF-A in macrophages. However, further evidence is required. It is well known that IL-6 is also considered to be major immune and inflammatory mediator in cancer. The present study indicated that the macrophages were induced to enhance the secretion and expression of the IL- 6 cytokines by BSF-A. These results indicate that these cytokines may be involved in the antitumor effect of BSF-A.

Antitumor activity of BSF-A in vitro. The majority of laryngeal cancers, also called cancers of the larynx or laryngeal carcinomas, are squamous cell carcinomas. Their features reflect their origin from squamous cells prior to forming the majority of the laryngeal epithelium. Laryngeal cancer may spread to adjacent structures by direct extension, to regional cervical lymph nodes by metastasis or to further regions, such as the lung, through the blood stream (32). As a robust cell line, Hep-2 is able to resist temperature, nutritional and environmental changes and maintain viability. Hep-2 has been broadly used for tumor production studies in rats, mice, hamsters, 
Table V. qPCR array analysis of the gene expression profile of the Hep-2 cells.

\begin{tabular}{ccccccccc}
\hline No. & 1 & 2 & 3 & 4 & 5 & 6 & 7 & 8 \\
\hline 1 & 1.62 & 0.02 & 0.01 & 1.67 & 2.11 & 1.73 & 0.32 & 1.03 \\
& ACIN1 & CASP10 & CD27 & E2F1 & IKBKB & MADD & NFKB1 & RELA \\
2 & 0.01 & 1.23 & 2.34 & 0.23 & 0.78 & 0.74 & 0.02 & 0.76 \\
& AIFM1 & CASP2 & CD40LG & E2F2 & IKBKG & MAP3K1 & NFKBIA & RIPK1 \\
3 & 0.01 & 0.06 & 1.09 & 7.78 & 0.87 & 2.81 & 1.89 & 0.55 \\
& AIFM2 & CASP3 & CD5 & EGFR & IL10 & MAP3K10 & NTRK1 & STAT1 \\
4 & 1.88 & 0.04 & 0.00 & 2.23 & 0.07 & 0.46 & 0.88 & 0.85 \\
& AKT1 & CASP4 & CD70 & E40OG & IL1A & MAP3K11 & PDCD1 & STAT5A \\
5 & 3.25 & 0.03 & 0.01 & 0.54 & 0.13 & 5.35 & 0.04 & 1.44 \\
& AKT2 & CASP5 & CDC2 & ERBB3 & IL1B & MAP3K14 & PDCD4 & STAT5B \\
6 & 0.03 & 0.04 & 0.17 & 2.48 & 0.01 & 0.11 & 0.13 & 2.92 \\
& AKT3 & CASP6 & HLA-A & FADD & IL2 & MAP3K5 & PDCD7 & TGFB1 \\
7 & 0.57 & 0.19 & 2.67 & 0.40 & 0.16 & 0.14 & 0.02 & 0.00 \\
& APAF1 & CASP7 & CIDEB & FASLG & IL4 & MAPK1 & PIK3CA & TNF \\
8 & 0.00 & 0.67 & 3.23 & 0.37 & 1.13 & 1.78 & 0.00 & 0.35 \\
& API5 & CASP8 & DAPK1 & IFNA2 & IL6R & MAPK3 & PIK3CG & TNFRSF10A \\
9 & 0.01 & 0.09 & 0.01 & 0.46 & 0.19 & 0.23 & 1.22 & 1.12 \\
& BCL2 & CASP9 & HLA-B & IFNB1 & IL7 & MAPK8 & PIK3R2 & TNFRSF10B \\
10 & 0.02 & 0.35 & 5.11 & 0.47 & 4.13 & 0.04 & 0.01 & 0.41 \\
& BIRC2 & CD226 & DAPK3 & IGF1 & IRAK1 & MAPK9 & PPP3CC & TP53 \\
11 & 0.02 & 0.12 & 0.12 & 1.12 & 0.05 & 1.88 & 0.37 & 0.45 \\
& BIRC3 & CD24 & DFFA & IGF1R & JAK2 & MYD88 & PPP3R1 & XIAP \\
& & & & & & & &
\end{tabular}

The values in the table are the relative expression multiples of each gene. Numbers 1-8 in the heading are the hole numbers in the chip.
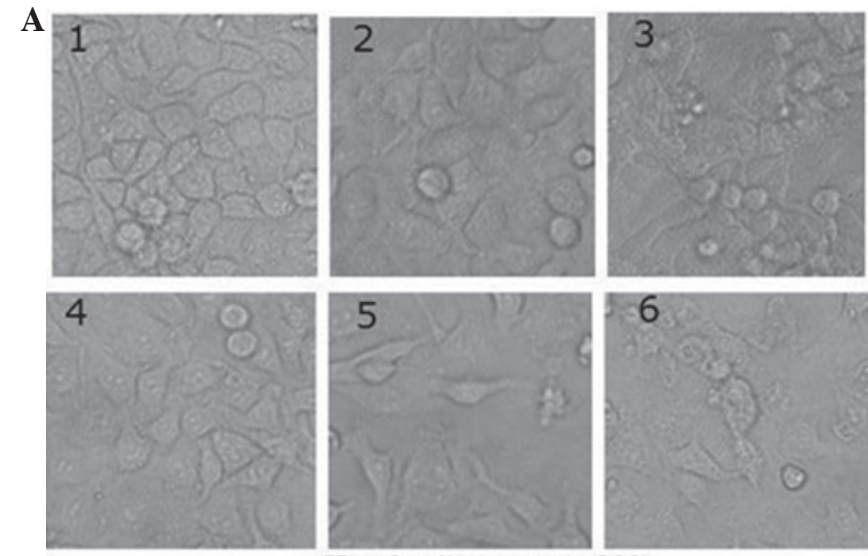

Hep-2 cells group $(\times 200)$
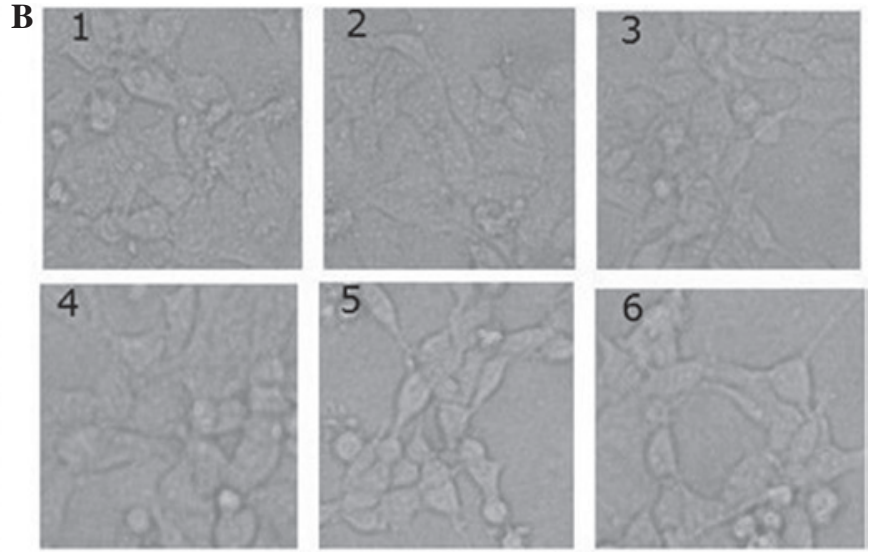

HepG2 cells group $(\times 200)$

Figure 6. Effect of BSF-A on morphology of (A) human laryngeal carcinoma Hep-2 cells and (B) human hepatoma Hep G-2 cells for 0, 25, 50, 100, 200 and $400 \mu \mathrm{g} / \mathrm{ml}$ (images 1-6, respectively).

embryonated eggs and volunteer terminal cancer patients (33). Human hepatocellular carcinoma HepG2 cells are epithelial in morphology and are capable of secreting various types of plasma proteins, including albumin, acute phase proteins, fibrinogen, transferrin, plasminogen, $\alpha 1$-antitrypsin and a2-macroglobulin transferrin (34). The present experiments demonstrated variability in the results due to the differences between these two types of cancer cells. As shown in Fig. 5, the human laryngeal carcinoma Hep-2 cells treated with $25-600 \mu \mathrm{g} / \mathrm{ml}$ BSF-A for $24 \mathrm{~h}$ exhibited significant cell growth inhibition $(\mathrm{P}<0.01, \mathrm{n}=6)$ compared with the control (untreated) cells when assayed using MTT. For comparison, human hepatoma HepG2 cells exhibited no significant change ( $\mathrm{P}>0.01, \mathrm{n}=6)$ when compared with the control (untreated) cells (Fig. 5). BSF-A had a time- and dose-dependent effect on Hep-2 and HepG2 cell growth inhibition, and a concentration of $400 \mu \mathrm{g} / \mathrm{ml}$ had the best rate of growth inhibition, which were 35.9 and $13.3 \%$, respectively.

The 96-well plates were placed under an inverted microscope. A camera recorded the changes in cell morphology for 
the varying concentration in order to measure the effect that BSF-A exhibited on the high anticancer activity. This could be observed from the cell morphology, which broke up and even fragmented in the Hep-2 group, while the HepG2 cells exhibited no significant changes compared with the control group (Fig. 6).

Apoptosis is a genetically controlled mechanism for cell death that is also involved in the regulation of tissue homeostasis. There are two major pathways of apoptosis that may be observed in the cytoplasm. The extrinsic pathways include fas and other tumor necrosis factor receptor superfamily members and ligands, and the intrinsic pathways are mitochondria-associated. The mitogen-activated protein kinase (MAPK) cascade is a highly-conserved module involved in various cellular functions, including cell proliferation, migration and differentiation. qPCR array analysis of the gene expression profile of the Hep-2 cells indicated that the anticancer activities of BSF-A on these cells may involve the MAPK signaling pathway for cell apoptosis (Table V). The complete signaling pathway for apoptosis of Hep-2 cells requires further study. The results obtained in the present study indicate that the purified polysaccharide of Boletus speciosus Frost may be a potential source of natural anticancer substances.

\section{Acknowledgements}

This project was supported by the National Natural Science Foundation of China (31200012), the Application Foundation Project of Sichuan Province (2013JY0094), the Science and Technology Support Project of Sichuan Province (2014SZ0020 and 2014FZ0024), the Cultivate Major Projects of Sichuan Province (14CZ0016) and the Doctor Startup Foundation Project of China West Normal University (11B019 and 11B020).

\section{References}

1. Hibbett DS, Binder M, Bischoff JF, Blackwell M, Cannon PF, Eriksson OE, et al: A higher level phylogenetic classification of the Fungi. Mycol Res 111: 509-547, 2007.

2. Bertozzi CR and Kiessling LL: Chemical glycobiology. Science 291: 2357-2364, 2001.

3. Wasser SP: Medicinal mushrooms as a source of antitumor and immunomodulating polysaccharides. Appl Microbiol Biotechnol 60: 258-274, 2002.

4. Borchers AT, Stern JS, Hackman RM, Keen CL and Gershwin ME: Mushrooms, tumors, and immunity. Proc Soc Exp Biol Med 221: 281-293, 1999

5. Rudd PM, Elliott T, Cresswell P, Wilson IA and Dwek RA: Glycosylation and the immune system. Science 291: 2370-2376, 2001.

6. Chen Y, Xie MY, Nie SP, Li C and Wang YX: Purification, composition analysis and antioxidant activity of a polysaccharide from the fruiting bodies of Ganoderma atrum. Food Chem 107: 231-241, 2008.

7. Angeli JP, Ribeiro LR, Gonzaga ML, Soares Sde A, Ricardo MP, Tsuboy MS, Stidl R, Knasmueller S, Linhares RE and Mantovani MS: Protective effects of beta-glucan extracted from Agaricus brasiliensis against chemically induced DNA damage in human lymphocytes. Cell Biol Toxicol 22: 285-291, 2006.

8. Li SP, Zhao KJ, Ji ZN, Song ZH, Dong TT, Lo CK, Cheung JK, Zhu SQ and Tsim KW: A polysaccharide isolated from Cordyceps sinensis, a traditional Chinese medicine, protects PC12 cells against hydrogen peroxide-induced injury. Life Sci 73 2503-2513, 2003.

9. Hetland G, Johnson E, Lyberg T, Bernardshaw S, Tryggestad AM and Grinde B: Effects of the medicinal mushroom Agaricus blazei Murill on immunity, infection and cancer. Scand J Immunol 68: 363-370, 2008.
10. Firenzuoli F, Gori L and Lombardo G: The medicinal mushroom Agaricus blazei Murrill: Review of literature and pharmaco-toxicological problems. Evid Based Complement Alternat Med 5: 3-15, 2008.

11. Paterson RR: Ganoderma - a therapeutic fungal biofactory. Phytochemistry 67: 1985-2001, 2006.

12. Paterson RR: Cordyceps: a traditional Chinese medicine and another fungal therapeutic biofactory? Phytochemistry 69: $1469-1495,2008$

13. Sullivan R, Smith JE and Rowan NJ: Medicinal mushrooms and cancer therapy: translating a traditional practice into Western medicine. Perspect Biol Med 49: 159-170, 2006.

14. Yang P, Liang M, Zhang Y and Shen B: Clinical application of a combination therapy of lentinan, multi-electrode RFA and TACE in HCC. Adv Ther 25: 787-794, 2008.

15. Fisher M and Yang LX: Anticancer effects and mechanisms of polysaccharide-K (PSK): implications of cancer immunotherapy. Anticancer Res 22: 1737-1754, 2002.

16. Ding X, Hou YL and Hou WR: Structure elucidation and antioxidant activity of a novel polysaccharide isolated from Boletus speciosus Frost. Int J Biol Macromol 50: 613-618, 2012.

17. Staub AM: Removal of proteins - Sevag method. Methods Carbohydr Chem 5: 5-6, 1965.

18. Dubois M, Gillis KA, Hamilton JK, Rebers PA and Smith F: Colorimetric method for determination of sugars and related substances. Anal Chem 28: 350-356, 1956.

19. Shantha LK, Lynette D and Andrew L: Preparation and characterisation of chitosan microspheres for antioxidant delivery. Carbohydr Poly 64: 163-167, 2006.

20. Yin Z, Jia R, Gao P, Gao R, Jiang D, Liu K and Liu S: Preparation of contraceptive pill microcapsule and its anti-fertility effect. Sheng Wu Yi Xue Gong Cheng Xue Za Zhi 21: 979-982, 2004 (In Chinese).

21. Cho JS, Kwon A and Cho CG: Microencapsulation of octadecane as a phase-change material by interfacial polymerization in an emulsion system. Colloid Polym Sci 280: 260-266, 2002.

22. Keller R, Geiges M and Keist R: L-arginine-dependent reactive nitrogen intermediates as mediators of tumor cell killing by activated macrophages. Cancer Res 50: 1421-1425, 1990.

23. Anna S, Harald DH and Stöver X: Polymer microcapsules by interfacial polyaddition between styrene-maleic anhydride copolymers and amines. J Membr Sci 209: 421-432, 2002.

24. Rasenack N, Hartenhauer H and Müller BW: Microcrystals for dissolution rate enhancement of poorly water-soluble drugs. Int J Pharm 254: 137-145, 2003.

25. Ooi VE and Liu F: Immunomodulation and anti-cancer activity of polysaccharide-protein complexes. Curr Med Chem 7: 715-729, 2000

26. Fidler IJ and Kleinerman ES: Therapy of cancer metastasis by systemic activation of macrophages; from bench to the clinic. Res Immunol 144: 284-287, discussion 294-298, 1993.

27. Flick DA and Gifford GE: Comparison of in vitro cell cytotoxicity assays for tumor necrosis factor. J Immunol Methods 68: 167-175, 1984.

28. Klostergaard J: Macrophage tumoricidal mechanisms. Res Immunol 144: 274-276, 1993.

29. Klimp AH, deVries EG, Scherphof GL and Daemen T: A potential role of macrophage activation in the treatment of cancer. Crit Rev Oncol Hematol 44: 143-161, 2002.

30. Goossens V, Grooten J, De Vos K and Fiers W: Direct evidence for tumor necrosis factor-induced mitochondrial reactive oxygen intermediates and their involvement in cytotoxicity. Proc Natl Acad Sci USA 92: 8115-8119, 1995.

31. Kröncke KD, Fehsel K and Kolb-Bachofen V: Inducible nitric oxide synthase and its product nitric oxide, a small molecule with complex biological activities. Biol Chem Hoppe Seyler 376: 327-343, 1995.

32. Yu L, Li HZ, Lu SM, Liu WW, Li JF, Wang HB and $\mathrm{Xu} \mathrm{W}$ : Alteration in TWIST expression: possible role in paclitaxel-induced apoptosis in human laryngeal carcinoma Hep-2 cell line. Croat Med J 50: 536-542, 2009.

33. Nutting CM, Robinson $M$ and Birchall M: Survival from laryngeal cancer in England and Wales up to 2001. Br J Cancer 99 (Suppl 1): S38-S39, 2008

34. Chen CC and Chan WH: Inhibition of citrinin-induced apoptotic biochemical signaling in human hepatoma G2 cells by resveratrol. Int J Mol Sci 10: 3338-3357, 2009. 